\title{
Executive remuneration in South Africa: key issues highlighted by shareholder activists
}

\author{
Author: \\ Prof Suzette Viviers ${ }^{1}$ \\ Affiliation: \\ 'Department of Business \\ Management, Stellenbosch \\ University, Private Bag X1, \\ Matieland, 7602, \\ South Africa
}

\section{Correspondence to:}

Prof Suzette Viviers

Email:

sviviers@sun.ac.za

DOI:

10.15249/9-1-112

\section{Keywords:}

Executive remuneration; institutional investors; individual investors; shareholder activism; Theo Botha; wage gap; proxy voting; South Africa

\section{Abstract}

The growing wage gap in South Africa has far-reaching socioeconomic consequences. This study investigated the nature of executive remuneration issues raised by shareholder activists in the country. An analysis of 24510 votes cast by 17 investment managers at 347 companies listed on the Johannesburg Stock Exchange in 2013 revealed that the vote to endorse companies' executive remuneration policies evoked the most opposition. Well-known shareholder activist, Theo Botha, also criticised companies for failing to disclose sufficient details on their remuneration policies. A disconnect between the performance of companies and their executives' pay was also noted. It is recommended that the non-binding vote on executive remuneration be revised and more investor education provided.

\section{Introduction}

The role of ethics in investing has long been debated in academic circles. In one of the first articles on the topic, Irvine (1987: 236) introduced the Enablement principle. This principle states that it is morally wrong for a person to do something that enables others to do wrong. In a corporate context, this principle implies that shareholders should not enable managers to do wrong. For the purposes of this article, corporate wrongdoing is seen to extend beyond obvious acts of unethical behaviour (such as the misappropriation of funds) to the perpetuation of an unjust society.

South Africa has one of the largest wage gaps in the world. A 2013 study found that chief executive officers (CEOs) of companies listed on the Johannesburg Stock Exchange (JSE) earned as much as 53 times the amount of the average worker 
in their companies (Bronkhorst, 2014). The top seven CEOs earned a staggering 300 times that of the average worker.

The remuneration committees of JSE-listed companies, however, justify executives' large compensation packages by stating that they need to attract, retain and motivate talented individuals (Hogg, 2008; Gilmour, 2013). This point, often made by companies that compete globally (Bronkhorst, 2014), is not without some merit. A remuneration committee that approved a substantial increase in its CEO's emolument package remarked: "No matter how immoral executive remuneration may seem to be to the rest of us, it has to be competitive. We simply can't afford to be bold in terms of the moral side of the equation and cut executive pay, because we would then run a real risk of losing some of our talented executives who have specialised knowledge and skills and who are also very mobile" (Barron, 2014a).

Some South African executives also believe that they are entitled to large compensation packages (Crotty, 2014c). The CEO of a major platinum mine allocated R76,4 million (+/- US\$7,64 million) in share options to 12 executives, at a time when the company refused to increase the minimum wage to R12 500 (+/- US\$1 250) per month, justifying the decision as follows: "Am I [the CEO] getting paid on a fair basis for what I'm having to deal with in this company? Must I run this company and deal with all this nonsense for nothing? I'm at work. I'm not on strike. I'm not demanding to be paid what I'm not worth" (Rose, 2014). The CEO later apologised for his public outburst (Patton, 2014).

The strike that the abovementioned CEO referred to was the worst mining strike in South Africa's history. It lasted for five months and forced businesses in Rustenburg to their knees, a city where mining-related activities account for about half the jobs and 60 per cent of the local economy (Burkhardt \& Janse, 2014). Mineworkers who did not receive their monthly salaries as a result of the "no-work, no-pay" principle, defaulted on their payments at furniture stores and other businesses where they had bought on credit. Tuck shops, street vendors and taxi operators were also adversely affected by the strike as they rely heavily on mineworkers for their income (Tau, 2014).

The mounting discontent among mineworkers also sparked a countrywide strike by the National Union of Metal Workers of South Africa in July 2014. Workers were quoted as saying that CEOs were being paid according to Western standards, while they "remain stuck in the third world" (Pickworth, 2014).

The growing wage gap and associated stakeholder discontent is not unique to South Africa. As far back as 1990, Jensen and Murphy investigated public claims of "excessive" executive compensation in the United States (US). They argued that executive remuneration was not necessarily "excessive", but expressed concerns about the disconnect between company performance and the nature of performance incentives offered to executives. The authors called on boards to allocate a larger percentage of their company's equity to CEOs, offer substantial cash rewards for outstanding performance and impose meaningful penalties for poor performance. 
Since the publication of Jensen and Murphy's (1990) seminal article, many other researchers have also determined that executives' salaries and incentives are practically independent from company performance (Conyon, 1997; Vitulano \& Hannafey, 2009; Faulkender et al., 2010; Purcell, 2011). Recommendations on how to restructure and rein in executive remuneration has ranged from legislation to allocating stock options and improving the public disclosure of executive remuneration policies and practices (Chan, 2009).

Levitt (2004) claimed that the single greatest impediment to the restoration of confidence in corporate America after the bursting of the dot.com bubble was "continuing instances of extravagant non-performance-based compensation". The same argument resurfaced after the 2008 financial crisis and resulted in shareholders across the globe taking a more active interest in the topic of performance-based executive remuneration (Del Guercio et al., 2008; Bhagat \& Romano, 2009; Palmon et al., 2009; Ferri \& Maber, 2013).

Although shareholder activism is not a new phenomenon (Waddock \& Graves, 2004), it is increasingly seen as an effective means of promoting change in corporate policies and practices, including those dealing with executive emolument (Del Guercio \& Tran, 2012). A number of mechanisms available to shareholders to monitor and exert pressure on managers are set out in Table 1.

Table 1: Shareholder activism mechanisms

\begin{tabular}{|l|l|}
\hline Nature of engagement & Mechanism \\
\hline Private (informal) efforts by & Writing letters \\
\cline { 2 - 2 } shareholders to initiate change & Negotiating with management in private \\
\cline { 2 - 2 } & $\begin{array}{l}\text { Divesting (i.e. selling all the shares owned in a company that fails to } \\
\text { respond to shareholders' requests to transform) }\end{array}$ \\
\cline { 2 - 2 } & Legal proceedings to enforce shareholder rights \\
\hline \multirow{2}{*}{ Public (formal) endeavours by } & Filing of shareholder resolutions \\
\cline { 2 - 2 } & Asking questions at annual general meetings (AGMs) \\
\cline { 2 - 2 } & Voting proxies \\
\cline { 2 - 2 } & $\begin{array}{l}\text { Stimulating public debate on issues of concern (e.g. by raising issues } \\
\text { at conferences or talking to the media) }\end{array}$ \\
\hline
\end{tabular}

Sources: Karpoff et al., 1996; Guay et al., 2004; McLaren 2004; Hendry et al., 2007; De Bakker and Den Hond, 2008; Gifford, 2010; Judge et al., 2010; Morgan et al., 2011; Nordén \& Strand 2011.

A strong case can be made as to why shareholders should monitor and influence managers' actions for their own and the greater good. This case is based on the notions of reciprocity, interdependence and accountability (Goodstein \& Wicks, 2007). It has long been recognised that moral relationships are reciprocal and deeply influenced by the respective parties' perceptions of fairness. Philips (1997) posits that "whenever persons or groups of persons voluntarily accept the benefits of a mutual beneficial scheme of co-operation, requiring sacrifice or contribution on the parts of the participants, and 
there exists the possibility of free-riding, obligations of fairness are created among the participants in the co-operative scheme in proportion to the benefits accepted."

When applying Philips' argument to a corporate context, it is clear to see why shareholders have an obligation of fairness. Not only do they voluntarily accept the benefits (dividends and capital gains) from jointly funding the operations of a company, but there is also the very real possibility of free riding. As will be shown later in this article, very few shareholders in South Africa take the time or effort to engage with managers on matters related to corporate wrongdoing.

Shareholder responsibility also arises from the interdependence between shareholders, firms and society. The Latin root of the word responsibility is respondere which literally means to "pledge back" and involves a continuous commitment to the greater good. According to Goodstein and Wicks (2007), this interpretation of responsibility emphasises the notion that shareholders and managers share a common fate and suggest that both parties should "pledge things to each other so as to foster co-operation and enhance the welfare of society". Whereas some "pledges" are explicit and formalised, others are reinforced through implicit norms, based on trust. In the context of this research, shareholders could pledge their continued support for management (for example by reelecting certain individuals) if management undertakes to compensate executives in an equitable manner.

A third way of understanding shareholder responsibility is connected to the notion of accountability. Goodstein and Wicks (2007) claim that the most important way in which shareholders and managers can honour their "pledges" is through making morally acceptable decisions and being accountable for their actions and impacts. A key consideration in determining accountability is whether the party in question has the capacity to produce consequences that matter to others. As illustrated earlier, decisions relating to executive remuneration could disrupt the lives of employees and those who depend on their income. As future dividends and capital gains are also likely to be adversely affected by disruptions to social cohesion, shareholders have a definite interest in ensuring fair decision making in this regard.

As the enablers and beneficiaries of corporate activity, shareholders have a responsibility, not only to monitor managers' behaviour for any wrongdoing, but also to influence their decisions to contribute to the greater good (or common fate as Goodstein and Wicks (2007) calls it). Nowhere is this responsibility more apparent than in the recent debate on excessive executive remuneration.

\section{Problem Statement and Research Objectives}

very few academic studies have been undertaken on the mechanisms used by shareholder activists in South Africa. Whereas Veicht (1995) investigated the role of institutional investors in addressing weak corporate governance among JSE-listed companies, Bhana (2010) considered the matter from an individual investor perspective. The legal aspects associated with shareholder activism were evaluated by Rademeyer and Holtzhausen 
(2004) and Lekhesa (2009), while Fumpa (2011) and Reddy and Giamporcaro (2011) explored the role of trade unions in engaging investee companies. For the rest reference is only briefly made to shareholder activism in articles dealing with responsible investing in South Africa, for example Heese (2005) and Viviers et al. (2009).

To address the gap in the literature, this article will provide an overview of shareholder activism in South Africa, both from an institutional and individual investor perspective. Specific attention will be paid to the executive remuneration issues raised by local shareholder activists. Insight into the executive compensation issues that provoke shareholder opposition could enable JSE-listed companies to be more proactive on the matter, thereby avoiding reputational damage.

The remainder of the study is structured as follows: In the next section, an introduction to and overview of shareholder activism will be presented, both internationally and in South Africa. The methods used to collect and analyse data will then be presented followed by the main findings and recommendations for remuneration committees, academics and the South African regulator.

\section{Shareholder Activism: An Introduction to the Phenomenon}

Shareholder activists are investors who use their equity stake in a company (called the investee company) to question managerial decisions and demand accountability. Investors are typically classified as institutional investors (such as pension funds, insurance companies, banks and collective investment schemes) or as individual investors (Renneboog et al., 2008). Religious groups in the US were the first institutional investors to publicly raise their concerns about human rights and labour standards as early as the 1940s. Public pension funds only followed suit in the 1980s after religious and other activist organisations established the legitimacy of the social issue agenda (Proffitt \& Spicer, 2006).

As "bastions of capital", public and private pension funds have a critical role to play in redressing "inflamatory imbalances between executive and worker remuneration" (Picketty, 2014). The literature review suggests that pension funds and other institutional investors are slowly beginning to take their responsibility more seriously in curbing the wage gap (Sjöstrom, 2008; Wen, 2009; Poulsen et al., 2010; Hadani et al., 2011). Given their size, institutional investors have more incentives and resources to monitor the actions of remuneration committees compared with their individual counterparts (Gillan \& Starks, 2000, 2007; Almazan et al., 2005).

In addition to the mechanisms listed in Table 1, shareholders who are not satisfied with the manner in which managers respond to their requests, could also do the so-called "Wall Street Walk", that is, they could sell all the shares they own in a specific company and invest elsewhere (Meznar et al., 1998; Admati \& Pfleiderer, 2009). This shareholder activism mechanism is generally only used by institutional investors, as divestment by individual investors does not have a significant impact on a company's share price or cost of capital. 
Institutional shareholder activism received a significant boost in 2006 with the launch of the United Nations' Principles for Responsible Investment (PRI). PRI signatories are encouraged to be active owners who incorporate environmental, social and corporate governance (ESG) considerations into their ownership policies and practices. On 31 December 2014, 286 asset owners in 27 countries were PRI signatories. It is estimated that these owners manage assets to the value of US\$45 trillion (UNPRI, 2015).

Research shows that the mechanisms used by shareholder activists differ from country to country. Activists in the United Kingdom (UK) and Sweden, for example, prefer private forms of activism (Short \& Keasey, 1999; Becht et al., 2010; Poulsen et al., 2010), while public activism is more evident in the US (Bauer et al., 2012).

Most cases of shareholder activism is financially motivated and involves, among others, pressurising management to spin-off loss-making divisions and increase dividend payouts (Ntim et al., 2012). In contrast to shareholder activists' financial motivation, sociallyorientated shareholder activists endeavour to create a more just society (Hendry et al., 2007). Issues pertaining to sustainability, human rights and labour standards are thus often high on the agenda of social shareholder activists (Proffitt \& Spicer, 2006). Although executive remuneration has financial implications, activism on this issue is generally classified as social rather than financial.

Nordén and Strand (2011) ascribe the rise in social shareholder activism to a growing number of investors wanting to comply with external, normative pressures such as culture, law, politics, informal codes of conduct, and societal expectations. Some authors (such as Cespa \& Cestone, 2007) contend that financial and social shareholder activism are converging, and attribute this trend to a growing realisation among companies and shareholders of their mutual dependence. McLaren (2004) also a mutual interest in the collective social benefits that can result from engagement among shareholders and companies.

The extent to which institutional investors monitor managers' behaviour, be it financially or socially driven, has been shown to be positively associated with company size (Waddock \& Graves, 2004; Ng et al., 2009; Judge et al., 2010), poor prior financial performance of a company (Karpoff et al., 1996), inadequate corporate governance (Morgan et al., 2011) and significant institutional ownership (Bauer et al., 2012). A number of factors that have a negative impact on activism intensity have also been identified in the literature. These include concerns about fiduciary duty (Almazan et al., 2005), potential business relations with investee companies (Davis \& Han Kim, 2007) and the so-called "free rider" problem that exists due to the private cost of monitoring (Shleifer \& Vishny, 1986).

The rise in shareholder activism has not been without controversy. The phenomenon has been described as "disruptive, opportunistic, misguided and at best ineffective" (Becht et al., 2010: 3094). Hendry et al. (2007) point out that some managers resent being told how to run their companies by investors who have no management experience. However, these managers should realise that investors also resent it when managers destroy shareholder value, whatever the reason may be. 
The question of how effective shareholder activists have been in influencing corporate decision making on policies and practices has been extensively researched (Wen, 2009). Mixed evidence has been reported on shareholders' ability to influence the level and composition of executive pay packages. Thomas and Martin (1999), for example, found that individual shareholder activists have not been successful in amending executive remuneration policies. The authors attributed their findings to the limited capacity of individual shareholders to understand and monitor complex compensation policies.

As far as institutional investors are concerned, a number of studies reported that "against" or "no" votes at AGMs have been ineffective in reducing executive remuneration and/or restructuring emolument packages (Conyon \& Sadler, 2010; Armstrong et al., 2013). In contrast to these findings, Ferri and Maber (2013) ascertained that many UK companies removed controversial CEO remuneration practices, such as generous severance contracts, and by increasing the sensitivity of performance-based bonuses in response to negative say-on-pay votes. A significant reduction in CEO remuneration as a result of shareholder opposition were also reported by Cheffins and Thomas (2001) and Ertimur et al. (2010).

As indicated earlier, very limited academic research has been done on shareholder activism in South Africa. In the following section an attempt will thus be made to present an overview of the mechanisms used by institutional and individual shareholder activists in the country.

\section{Shareholder Activism in South Africa}

In view of the relatively small size of the $\mathrm{JSE}^{1}$, divestment is generally not used as a shareholder activism mechanism by South African institutional investors (Boshoff \& Schulshenk, 2014). Withdrawing from an already limited investment universe will leave institutional investors with poorly diversified domestic portfolios (Baue, 2002). In contrast to the US, local shareholders hardly ever revert to legal proceedings and the filing of shareholder resolutions to enforce their rights (Lekhesa, 2009; Silverman \& Duncan, 2014). Local institutional investors furthermore have a poor track record when it comes to asking questions and voting at AGMs (Barron, 2008; Crotty, 2010; Mathews \& Hasenfuss, 2013). Barron (2011) claims that this passiveness "goes back to the bad old days when there was an old boys' network. You had the mining houses and the banks and everybody owned shares in each other and they all met at the Rand Club, and nobody rocked the boat".

The Government Employees Pension Fund (GEPF) was one of the pioneers of shareholder activism in South Africa. The GEPF is the largest pension fund in the country, with more than 1,2 million active members and assets worth more than R1 trillion (+/- US\$1,25 billion) (GEPF, 2015a). Being one of the founding members of the United Nations' Principles for Responsible Investment in 2006, the GEPF is committed to use its financial strength to build a better society (GEPF, 2015b). Although the pension fund occasionally engages with investee companies, most of its activism initiatives are outsourced to the 
Public Investment Corporation (PIC). The PIC also invests on behalf of other public sector entities, and is thus one of the largest asset managers in Africa (PIC, 2015).

Under the leadership of Brian Molefe (2003-2010) the PIC publically engaged with several JSE-listed companies, mainly on transformation-related matters (Robbins, 2008; Mantshantsha, 2013). Following the appointment of the new CEO, Dr Dan Matjila, the PIC's approach to activism has changed considerably: "We [the PIC] engage with lots of companies behind the scenes, but prefer to keep details of discussions out of the media" (Barron, 2014b). Anecdotal evidence suggests that the majority of other institutional investors in South Africa also prefer to discuss their concerns with investee companies in private (Anderson, 2006; Cohen, 2011; Winfield, 2011)

To encourage institutional shareholder activism in the country, the Association of Savings and Investments SA compiled a Code for Responsible Investing in South Africa (CRISA, 2011). Developed in conjunction with the Institute of Directors Southern Africa and the Principal Officers Association, CRISA draws heavily on recommendations of the PRI and the third King report (the King III report) on corporate governance in South Africa.

Despite these positive developments as well as changes to pension fund legislation in 2011, institutional shareholder apathy is still endemic in the country (Crotty, 2014b; Couldridge, 2014). This state of affairs may be as a result of, among others, a lack of interest among trustees (Cairns, 2014), business relations between investment managers and investee companies, resulting in conflicts of interest (Crotty, 2012b), and inefficient skills among practitioners in the entire investment chain (Herringer et al., 2009). These barriers to shareholder activism are also reported in international research on the topic (Ng et al., 2009; Huppé \& Bala-Miller, 2011).

A number of individuals have become prominent shareholder activists in South Africa. These include Theo Botha, Issy Goldberg, Roy McAlpine, and a gentleman colloquially called "Mr Hayden" in the press (Barron, 2011; Carte, 2011). Of these, Theo Botha is by far the most vocal and well-known individual shareholder activist in the country (Bhana, 2010; Mpofu, 2013; Gardee, 2014; Shevel, 2014). Botha was born in 1960, and later obtained a Bachelor of Commerce (honours) degree in accounting at the University of South Africa (Unisa). He completed his articles at PricewaterhouseCoopers, but had to return to his family's farm in 1987 after his father passed away (Steyn, 2011). Currently, Botha is a part-owner and director of CA Governance, a leading independent corporate governance practitioner in South Africa (CA Governance, 2015).

After making a small investment in 2002 in the Sage Group, a South African life assurance company, Botha discovered that the company failed to disclose losses in its US operations to local shareholders (Keeping tycoons on their toes, 2007). He privately questioned management on the omission, but the company responded by saying that its financial statements complied with local disclosure requirements. Unsatisfied with the response, 
Botha raised the issue at the company's AGM. As he received the same brush-off as earlier, he decided to approach the media. Following the media reports, Sage's share price did not only fall dramatically, but its credit rating was also downgraded a few weeks later (Planting, 2012).

Since his initial deliberations with the Sage Group, Botha has engaged with numerous companies listed on the Johannesburg and London Stock Exchanges. His efforts in highlighting unsatisfactory accounting, financial and ESG practices, have earned him a reputation as a corporate watchdog, or to be more specific, a terrier (Creamer, 2009; Shevel, 2014). The so-called "Botha sting" has also resulted in a significant decrease in companies' share prices after being publically criticised by the activist (Bhana, 2010).

Given that individual shareholder activists rarely have access to corporate managers (De Bruin, 2014), their activism endeavours are essentially limited to raising questions at AGMs and in the media.

\section{Research Methodology}

A mixed methods approach was used to identify the key issues raised by shareholder activists on executive remuneration in South Africa. Given the absence of academic literature on the topic in South Africa, an extensive review of media and industry reports was thus necessary.

\section{Data collection and analysis: institutional shareholder activism in South Africa}

As most private negotiations between shareholder activists and investee companies in South Africa take place behind closed doors, no data were available to investigate the issues raised at these meetings. A decision was therefore made to focus on the proxy voting outcomes of a sample of local investment managers who invest on behalf of institutional shareowners. ${ }^{2}$ Publicly available proxy voting data for 2013 were gathered from the websites of 17 of the largest investment managers in South Africa. Where proxy voting data were not publicly available, it was requested directly from investment managers. Details on the domains, codes and sources of data used in constructing the proxy voting database are provided in Table 2.

Resolutions pertaining to preference shares, exchange traded funds, $\mathrm{N}$-shares and B-shares were excluded from the database. For comparative purposes, only resolutions tabled at AGMs in 2013 were analysed. A total of 24510 votes at 347 JSE-listed companies were analysed using descriptive statistics. ${ }^{3}$ 
Table 2: Description of the proxy voting database

\begin{tabular}{|c|c|c|}
\hline Domain & Code & Data source(s) \\
\hline $\begin{array}{l}\text { Name of investment } \\
\text { manager }\end{array}$ & $\begin{array}{l}\text { Abax Investments; Afena Capital; Allan Gray; Cadiz Asset } \\
\text { Management; Coronation Fund Managers; Element } \\
\text { Investment Managers; Foord Asset Management; } \\
\text { Futuregrowth Asset Management; Investec Asset } \\
\text { Management; Kagiso Asset Management; Old Mutual } \\
\text { Investment Group (SA); Public Investment Corporation; } \\
\text { Prescient Investment Management; Prudential Portfolio } \\
\text { Managers; Stanlib; Taquanta Asset Managers; Vunani Fund } \\
\text { Management }\end{array}$ & \\
\hline $\begin{array}{l}\text { Share code of } \\
\text { JSE-listed company }\end{array}$ & Share code & \\
\hline $\begin{array}{l}\text { Date of listing of } \\
\text { JSE-listed company }\end{array}$ & Date of listing & $\begin{array}{l}\text { Sharenet and } \\
\text { ShareData } \\
\text { websites }\end{array}$ \\
\hline $\begin{array}{l}\text { Industry classification } \\
\text { of JSE-listed } \\
\text { company }\end{array}$ & $\begin{array}{l}\text { Resources (J004); Basic industries (J010); General } \\
\text { industries (J020); Non-cyclical consumer goods (J030); } \\
\text { Cyclical consumer goods (J040); Cyclical services (J050); } \\
\text { Non-cyclical services (J060); Financials (J080); Information } \\
\text { technology (J090); AltX }\end{array}$ & $\begin{array}{l}\text { Sharenet and } \\
\text { ShareData } \\
\text { websites }\end{array}$ \\
\hline Meeting type & $\begin{array}{l}\text { Annual general meeting; General meeting; Extraordinary } \\
\text { general meeting; Scheme meeting; Special meeting }\end{array}$ & $\begin{array}{l}\text { Documents } \\
\text { available on } \\
\text { the investment } \\
\text { managers' } \\
\text { websites or } \\
\text { provided by them. }\end{array}$ \\
\hline Resolution & The exact wording of the resolution that was voted on & Ditto \\
\hline Resolution type & Ordinary; Special & Ditto \\
\hline Manager vote & For; Against; Abstain & Ditto \\
\hline "Against" theme & $\begin{array}{l}42 \text { codes categorising financial and corporate } \\
\text { governance-related resolutions }\end{array}$ & $\begin{array}{l}\text { The researchers' } \\
\text { own coding based } \\
\text { on terminology } \\
\text { used in the } \\
\text { Companies Act } \\
\text { (No. } 71 \text { of 2008), } \\
\text { the JSE listings } \\
\text { requirements and } \\
\text { the King III report }\end{array}$ \\
\hline Voting outcome & Passed; Rejected; Withdrawn & $\begin{array}{l}\text { RMB Custody and } \\
\text { Trustee Services }\end{array}$ \\
\hline
\end{tabular}

(a) The industry classification of the FTSE/JSE Africa Index Series (2014) was used.

\section{Data collection and analysis: individual shareholder activism in South Africa}

Considering Theo Botha's prominence as an individual shareholder activist in South Africa, a decision was made to focus on his endeavours over the period May 2002 to December 2014. Newspaper articles reporting on Botha's interactions with JSE-listed companies were identified using key words such as "Theo Botha", "Brian Molefe", "Public Investment Corporation" "PIC", "Government Employees Pension Fund", "GEPF”, "Code 
for Responsible Investing in South Africa", "CRISA", "Regulation 28”, "annual general meeting", "AGM", "shareholder activism", "shareholder engagement", "proxies”, "proxy voting", "resolutions", "institutional investors" and "minority investors".

To gain more insight into Botha's raison d'être, an in-depth personal interview was also conducted with the shareholder activist in July 2013. Follow-up discussions were held with him to verify the accuracy of data collected, and to determine whether there were any additional engagements not reported in the media. The collected data were coded and analysed using the three phases of deductive qualitative content analysis (Elo \& Kyngäs, 2007). In the first phase, a categorisation matrix was developed to code data according to categories (such as financial and ESG issues). Next, the data were reviewed and coded for correspondence with, or exemplification of, the identified categories. Finally, the contents of the categories were described by means of sub-categories. The category dealing with corporate governance issues was, for example, sub-divided into issues dealing with the board of directors, executive remuneration and communication with shareholders.

Botha consented to his name to be used in this study and was given the opportunity to verify the accuracy of the data. Care was taken to ensure the credibility and reliability of the findings.

\section{Empirical Findings}

\section{Institutional shareholder activism on executive remuneration in South Africa}

Only 6,6 per cent of all votes cast by the investment managers in the 2013 sample were "against" votes. However, informal discussions with selected investment managers revealed that the low percentage of "against" votes should not be viewed as investor inactivity, but rather as the result of successful private negotiations that took place with investee companies prior to the AGMs in 2013. Table 3 presents a summary of the executive remuneration resolutions that received opposition.

The "against" votes on executive remuneration issues represented 37,3 per cent of all “against" votes in 2013. The resolution requiring shareholder endorsement of a company's remuneration policy evoked the highest number of opposition votes of all 42 resolutions investigated in this study. As this vote is non-binding, remuneration committees do not have to amend their policies in response to the vote outcome. Despite the nonbinding nature of the vote on shareholder endorsement of a company's remuneration policy, research by Ernest \& Young (E\&Y) showed that a considerable number of local remuneration committees changed their remuneration policies in response to the 2013 vote. One third of the remuneration committees in the E\&Y survey regarded an "against" vote of 30 per cent or more as a warning signal of growing shareholder dissent (Remuneration Governance in South Africa - 2013 Survey results, 2013). 
Quite a few resolutions requiring shareholder approval in terms of directors' fees and performance incentives also attracted opposition in 2013. The findings of the current study support anecdotal evidence in earlier years that institutional investors are becoming more vocal about executive compensation in South Africa. For example, in 2011, the majority of shareholders vetoed a proposed 40 per cent increase in non-executive directors' fees at Spur Corporation, a local restaurant chain (Vallie, 2011). In the same year, Investec's Stephen Koseff was reported to be South Africa's highest-paid banker, despite the fact that the company showed the lowest returns among the country's five largest banks. Unsurprisingly, 28 per cent of shareholders opposed the company's remuneration policy in the following year (Vanek, 2012c). Shareholders were also quick to question the virtual doubling of the steel giant ArcelorMittal's CEO's remuneration package in 2012 (Filen, 2012). Also in 2012, the majority (75 per cent) of Central Rand Gold's shareholders voted against the company's director remuneration report (Faku, 2012). As this was the largest "no" vote to date recorded in South Africa, a clear message of shareholder dissent was sent to management.

Table 3: Executive remuneration-related resolutions that received "against" votes

\begin{tabular}{|c|c|c|c|}
\hline Category & Resolution & $\begin{array}{r}\text { No of res } \\
\text { receiving } \\
\text { vot }\end{array}$ & $\begin{array}{l}\text { ons } \\
\text { nst" }\end{array}$ \\
\hline Remuneration policy & Endorsing the company's remuneration policy & 228 & 228 \\
\hline \multirow{11}{*}{$\begin{array}{l}\text { Directors' fees } \\
\text { and performance } \\
\text { incentives }\end{array}$} & Approving non-executive directors' remuneration/fees & 95 & \\
\hline & Approving the share incentive plan & 21 & \\
\hline & $\begin{array}{l}\text { Approving the issue of shares to directors and/or } \\
\text { prescribed officers under the share incentive plan }\end{array}$ & 17 & \\
\hline & Issuing ordinary shares for the purpose of share options & 10 & \\
\hline & Approving the chairperson's remuneration/fees & 8 & \\
\hline & Amending the share incentive plan & 6 & \\
\hline & Approving the share option plan & 4 & \\
\hline & Adopting an employee forfeitable share plan & 3 & \\
\hline & Amending the long-term incentive plan & 2 & \\
\hline & Adopting the long-term incentive plan & 1 & \\
\hline & Approving the long-term incentive plan & 1 & 168 \\
\hline \multicolumn{2}{|l|}{ Total } & 396 & 396 \\
\hline
\end{tabular}

\section{Botha's concerns about executive remuneration in South Africa}

Before providing details on the executive remuneration issues raised by Botha, a short description is provided on his modus operandi. In line with institutional investors, Botha also prefers to target large, well-known companies (Bhana, 2010). Once a company has been selected, Botha prepares meticulously for the company's AGM. It could take him up to five hours to examine the company's annual report. He also reads at least five years' annual reports before attending a company's AGM (Barron, 2008) and scrutinises 
circulars and information posted on the web (Tredway, 2004). "From the Sage experience in 2002 l've learnt to read through a company's public information very closely". In a few cases, Botha sent his list of questions to managers prior to a company's AGM. As indicated in Table 4, he attended 143 AGMs of 58 JSE-listed companies over the period May 2002 to December 2014. In some of these cases, Botha only owned one share in a company to gain access to its AGM.

Table 4: Shareholder activism mechanisms used by Botha (May 2002-December 2014)(a)

\begin{tabular}{|l|r|}
\hline Mechanism & No of cases \\
\hline Asking questions at AGMs(b) & 143 \\
\hline Making comments about a specific company/director in the media(c) & 44 \\
\hline Engaging in private discussions with directors prior to or after an AGM & 8 \\
\hline Engaging with the JSE about misbehaving listed companies & 3 \\
\hline Initiating legal proceedings & 3 \\
\hline (a) These mechanisms are not mutually exclusive. Botha terms them as “different arrows for his bow" and suggests that \\
individual shareholder activists should use as many mechanisms as possible to convey their viewpoints. \\
(b) The names of the companies are listed in Appendix A. \\
(c) Media comments have increased considerably in 2014 as a result of a regular "soap box" insert which Botha writes for \\
Moneyweb [a South African online business newspaper].
\end{tabular}

Once at an AGM, Botha asks questions and insists that both his questions and directors' responses are minuted (Petros, 2009; Crotty, 2011). He believes that proper record keeping is necessary to hold directors accountable from one AGM to the next. Apostolides (2007: 1277) once remarked that companies often regard their AGM as "an annual headache where management is questioned by social activists". According to Rose (2007), South African managers are no exception, especially when Botha attended their AGMs. Table 5 provides a number of the executive remuneration issues which Botha raised with JSElisted companies, using one or more of the activism mechanisms described above.

Executive remuneration issues represented a fifth (21,9 per cent) of all issues that Botha has raised with JSE-listed companies over the past 13 years. Information in Table 5 confirms that inadequate disclosure of remuneration policies has been "a major bone of contention" for Botha. At present, JSE-listed companies are required by law to disclose details of executive and non-executive directors' fees and remuneration in their annual reports (Naidoo, 2002). The King III report recommends that this disclosure should be done on an individual basis, showing specific elements of each director's compensation package, i.e. basic salary, bonuses and share options. Botha's calls for better disclosure go a step further in that he wants to see more information on the performance targets, benchmarks and key performance indicators used by remuneration committees to determine the extent of executives' pay packages (Rose \& Shevel, 2009; De Waal, 2011; Vanek, 2012a; Crotty, 2013a; Hedley, 2013; Gilmour, 2014).

Botha argues that more information is necessary to hold remuneration committees accountable, and to determine whether executive pay is "appropriate or excessive" (Botha in Crotty, 2012a). The absence of accountability is further compounded by the lack of comparative figures from previous years (Schumacher \& Monteiro, 2009). In 2013, Botha commended a large banking group for improving its disclosure "on the complex issue of 
executive remuneration", but remarked that he still found it difficult to obtain a precise indication of the value of top managers' packages (Crotty, 2013b).

Table 5: Executive remuneration issues raised by Botha (May 2002-December 2014)(a)

\begin{tabular}{|c|c|c|c|}
\hline Category & Sub-category & \multicolumn{2}{|c|}{$\begin{array}{l}\text { No of times the } \\
\text { issue was raised }\end{array}$} \\
\hline Remuneration policy & $\begin{array}{l}\text { Poor or inadequate disclosure on the remuneration policy } \\
\text { (failure to disclose performance targets/benchmarks/key } \\
\text { performance indicators/caps and changes to the policy) }\end{array}$ & 24 & 24 \\
\hline \multirow{3}{*}{$\begin{array}{l}\text { Justification of the } \\
\text { size and composition } \\
\text { of executive } \\
\text { remuneration } \\
\text { packages }\end{array}$} & Justification of remuneration packages in general & 21 & \multirow[b]{3}{*}{41} \\
\hline & $\begin{array}{l}\text { Justification of remuneration packages in light of poor } \\
\text { financial performance }\end{array}$ & 18 & \\
\hline & $\begin{array}{l}\text { Justification of remuneration packages in light of } \\
\text { retrenchments and strikes }\end{array}$ & 2 & \\
\hline \multirow{2}{*}{$\begin{array}{l}\text { Composition and } \\
\text { responsibility of } \\
\text { remuneration } \\
\text { committees }\end{array}$} & $\begin{array}{l}\text { Questions related to the responsibility of the remuneration } \\
\text { committee (such as them serving the interests of directors } \\
\text { and not the interests of shareholders) }\end{array}$ & 8 & \multirow[b]{2}{*}{15} \\
\hline & $\begin{array}{l}\text { Concerns about the composition of the remuneration } \\
\text { committee (mainly deals with the independence of certain } \\
\text { committee members) }\end{array}$ & 7 & \\
\hline \multirow{2}{*}{$\begin{array}{l}\text { Directors' fees } \\
\text { and performance } \\
\text { incentives }\end{array}$} & Unequal treatment of directors in terms of rewards & 5 & \multirow[b]{2}{*}{9} \\
\hline & $\begin{array}{l}\text { Failure by the remuneration committees to link directors' } \\
\text { fees to their attendance of board meetings }\end{array}$ & 4 & \\
\hline \multirow{3}{*}{ Other } & $\begin{array}{l}\text { Inaccurate calculation or disclosure of bonuses, sign-on fees, } \\
\text { ex gratia fees, severance packages etc. }\end{array}$ & 7 & \multirow[b]{3}{*}{17} \\
\hline & $\begin{array}{l}\text { Concerns about the growing wage gap in a particular } \\
\text { company }\end{array}$ & 3 & \\
\hline & Other $^{(\mathrm{b})}$ & 7 & \\
\hline \multicolumn{2}{|l|}{ Total } & 106 & 106 \\
\hline \multicolumn{4}{|c|}{$\begin{array}{l}\text { a) The issues listed in this table are only those that appeared in local newspapers and magazines. Journalists may not have } \\
\text { reported on all the issues raised by Botha, as he sometimes had up to } 20 \text { questions (Mantshantsha, 2007). }\end{array}$} \\
\hline \multicolumn{4}{|c|}{$\begin{array}{l}\text { (b) "Other" remuneration issues dealt with directors receiving bonuses before shareholders had approved of it; the board's } \\
\text { endorsement of "excessive remuneration" at a time of weak commodity prices; directors' earning fees as a result of a pyramid } \\
\text { structure (rather than fees being based on performance), the allocation of broad-based black economic empowerment } \\
\text { shares to a white, female director, and unsecured loans being made available to directors on very lenient terms. }\end{array}$} \\
\hline
\end{tabular}

It is interesting to note that the vast majority of Botha's requests for improved remuneration disclosure $(86,5 \%)$ occurred after the 2008 global financial crisis. This finding concurs with increased appeals from investors around the globe for greater transparency on executives' emolument packages after 2008 (Palmon et al., 2009).

Botha has, on numerous occasions, requested boards to justify the size and composition of executives' compensation packages (Monterio, 2009; Crotty, 2012b; Vanek, 2012b; Mathews, 2014; Ndzamela, 2014). In the majority of these cases, the criticism was based on poor financial performance of the company in the same or preceding year (Benjamin, 2009; Hasenfuss, 2009a; Harris, 2013). Botha had particularly harsh criticism towards companies that increased executives' pay in the midst of destructive industrial action and/or retrenchments (Carte, 2009). The same applied to remuneration committees that ignored the growing wage gap in their company (Mantshantsha, 2007; Patton, 2014), and 
those that failed to cap performance bonuses allocated to executive managers (Whitfield, 2011). Botha was also opposed to non-executive directors who received fees despite their poor attendance of board and board committee meetings (Mamtse, 2007; Ashton, 2008; Barry, 2014b).

As a campaigner for sound corporate governance in South Africa (Hasenfuss, 2006), Botha is renowned for asking pressing questions about the size and lack of disclosure of sign-on fees, the allocation of share options, relocation allowances, ex gratia fees, and the clawing back of bonuses that have been paid to directors before shareholder approval was obtained (Hogg, 2009; Monteiro, 2009; Carte, 2010; Mantshantsha, 2010; Crotty, 2012a). Having repeatedly challenged the independence of directors who serve on remuneration committees (Cobbett, 2007; Mokopanele, 2008; Cokayne, 2009), Botha exposed a gross calculation error in a senior manager's remuneration package (Hasenfuss, 2009b). The manager in question also happened to be a member of the company's remuneration committee that approved the package.

Botha has also been very outspoken about local institutional investors' lack of activism, particularly on the topic of executive remuneration: "They are paying lip service to good governance and sustainability issues as they are under pressure to produce good results. They are notorious for keeping their costs tight, apart from when it comes to their bonuses" (Shevel, 2014). In a Moneyweb interview, during which Botha was asked why he was apparently the only person in South Africa who was concerned about executive remuneration, he responded: "I don't know. I wish there was somebody else. I wish the bigger shareholders would actually take this up because we are setting a bad precedent here. When the operating profits are down; when cash generation goes down, you would like to see a more balanced approach in terms of awarding bonuses" (Botha in Hogg, 2010).

Botha acknowledges that most institutional investors in South Africa prefer to engage with investee companies behind closed doors. However, in an effort to encourage greater transparency, he has repeatedly called on institutional investors to disclose the number of shares they vote at shareholder meetings, and how (for, against, abstain) they vote those shares: "Anything less leaves stakeholders in the dark" (Botha in Crotty, 2013c). Sadly, very few institutional investors have heeded Botha's calls to date.

\section{Summary and Conclusions}

Although a clear case exists for shareholder responsibility (based on the Enablement principle and the notions of reciprocity, interdependence and accountability), few investors in South Africa seem to take this responsibility seriously. The findings of this study show that institutional shareholder activism in South Africa mainly occurs by means of private negotiations and proxy voting. Despite amendments to pension fund legislation and initiatives such as the United Nations' Principles for Responsible Investment and the Code for Responsible Investing in South Africa, institutional shareholder activism in the country remains muted. Silverman and Duncan (2014) remarked that South Africa still 
has a long way to go in terms of maturity before the country will be ready to respond to shareholder pressure. As far as individual shareholder activism is concerned, Theo Botha remains a lone voice in the desert.

Local investment managers in this study voted against a number of resolutions pertaining to executive remuneration in 2013. Most of the shareholder dissent focused on the remuneration policies of investee companies. The issues brought to the fore by Botha provides more insight on the nature and extent of these concerns. After 2008, Botha has increasingly criticised JSE-listed companies for not disclosing sufficient information on the performance targets, benchmarks and key performance indicators used to determine executives' pay packages.

Although calls for improved disclosure have also been reported in international literature (Van Niekerk, 2014), these calls do not go unchallenged. Opponents argue that detailed public disclosure of CEOs' salaries has the unintended consequence of pushing these payments even higher. In this respect, a local remuneration committee commented that South African executives are very aware of what their counterparts are being paid: "If they think they're being short-changed, they leave. And believe me, in South Africa the pool of talented executives is very small. So the retention imperative is a very real one" (Barron, 2014a).

A second key issue highlighted in this study was the disconnect between executive emolument and company performance. Companies that fail to link managers' incentives to performance has received considerable condemnation from shareholder activists globally, particularly in the UK (Conyon \& Sadler, 2010; Ferri \& Maber, 2013). In South Africa, Botha has been exceptionally critical of poorly performing companies that still rewarded their executives by increasing their basic salaries and/or bonuses.

A 2012 survey among 30 JSE-listed companies revealed that several remuneration committees started to recognise the importance of this matter. Their first priority in 2012 was to design appropriation long-term incentive schemes followed by plans to link pay to performance (Harraway et al., 2012). However, the findings of this study seem to support Van Niekerk's (2014) claim that there is indeed a "mounting fury [from shareholders and other stakeholders] against the perceived exuberance of executive pay" in South Africa. In the following section a number of recommendations are provided to address the growing wage gap (and its adverse socio-economic consequences) in the country.

\section{Recommendations}

Evidence from this study suggests that shareholders are increasingly uncomfortable with the disclosure and application of executive compensation policies. However, as the vote on remuneration policy is non-binding, its impact is limited to signalling shareholder discontent. The regulator in South Africa has one of two options to address this matter. In the first instance, the regulator could consider changing the non-binding vote to a binding one as is the case in the UK and several European countries (Delman, 2010; Crotty, 2014b). 
Since October 2013, the remuneration reports of UK companies are required to not only outline the company's remuneration policy, but the reports should also contain details on how the policy was implemented in the financial year being reported on. Companies are further required to put their remuneration policies to a shareholder resolution at least every three years. As with other ordinary resolutions, a simple majority vote is needed for approval. Shareholders in the UK also have an annual advisory vote on a resolution to approve the implementation report, showing how the approved pay policy has been implemented. The latter should also contain a single figure indicating the total pay each director received in that year. Companies that wish to make changes to their remuneration policies should present the new policy to shareholders for approval at a general meeting.

Alternatively, the regulator could institute a so-called "two strike" law as in Australia (Botha, 2014). The Australian regulator amended that country's Corporations Act in July 2011 to hold directors more accountable for the salaries and bonuses they receive. The Act stipulates that each director's individual salary and bonus should be outlined in the report. The "first strike" occurs when a company's remuneration report receives an "against" vote of 25 per cent or more at the company's annual general meeting (AGM). The "second strike" occurs when the company's remuneration report again receives an "against" vote of 25 per cent or more at the next AGM. When this "second strike" occurs, the shareholders will vote at the same AGM to determine whether all the directors will need to stand for re-election (known as the "spill" resolution). If this "spill" resolution passes with 50 per cent or more of the eligible votes cast, a "spill meeting" has to take place within 90 days of the AGM. At this spill meeting, those individuals who were directors when the remuneration report was deemed unsatisfactory, will be required to stand for re-election, except for the managing director, who is permitted to continue to run the company (Jolly \& Bozinovski, 2013).

In an effort to improve disclosure among public companies, the JSE could consider revising its listing requirements. More stringent disclosure requirements would go a long way in empowering shareholders to make informed decisions. It is also suggested that companies publish more details on how shareholders vote at meetings. At present, listed companies are expected to inform the market, via the JSE's Stock Exchange News Service (SENS), of the outcome of the voting process. Although SENS statements such as "All resolutions were passed at the AGM" meet the JSE's listing requirements, they hardly reflect a pledge on the part of companies to be transparent. According to a market commentator, "the current [level of] disclosure is so brief as to be almost pointless" (Crotty, 2014b). If this status quo is set to change (as reported in the media), JSE-listed companies will be required to announce the total number of shares voted at their AGMs as well as the details of the outcome (for, against or abstain) (Crotty, 2014a).

It is furthermore proposed that entities such as the Association of Savings and Investments $\mathrm{SA}$, encourage their members (especially investment managers) to publish more details on their voting policies and practices. 
Although a few consulting companies already advise institutional investors on remuneration-related voting, more of these specialist services are necessary. Botha has established such a service for individual investors: "Whereas institutional investors have divisions and policies governing how they vote, many individual shareholders do not exercise their right to vote because of the effort required to make an informed decision" (Botha in Barry, 2014a). Botha hopes that his service will increase the number of shareholders who attend AGMs and participate on an informed basis, exercising their democratic right to vote (Botha in Barry, 2014a).

A more fundamental intervention to address the growing wage gap in South Africa lies with the education of future shareholders, pension fund trustees, asset managers and company directors. Much more attention should be given to ethics in mainstream financial and investment management qualifications, at both undergraduate and postgraduate level. Currently, it appears as if too much emphasis is placed on compliance with legislation and professional codes such as the King III report and the CFA's code of ethics and standards for professional conduct. As early as 1994, Paine (1994:111) asserted that "even in the best cases, legal compliance is unlikely to unleash much moral commitment. The law does not generally seek to inspire human excellence or distinction. It is no guide to exemplary behaviour - or even good practice. Those managers who define ethics as legal compliance are implicitly endorsing a code of moral mediocrity for their organisations".

It is therefore recommended that business educators should instil a greater sense of moral sensitivity, judgement and courage among their students. Case studies and other experiential learning techniques could be used to convey the value of social shareholder activism, and the responsibility that shareholders have in an emerging country to ensure the fair distribution of resources. The use of these techniques calls for the identification of successful shareholder activism examples in South Africa. More research is also required on the impact of shareholder activism on changing corporate policies and practices in South Africa, including those pertaining to executive remuneration.

In conclusion, the researcher wholeheartedly agrees with Botha that "it is time for institutional investors in South Africa to pick up the activism flame". In the words of Gide (in Davis et al., 2006) all South African investors, irrespective of size, should "work and struggle and never accept an evil that you can change". It is unacceptable that shareholders in South Africa continue the enablement of an unjust society by failing to monitor and influence managers' decisions, particularly as they pertain to the size and composition of executive remuneration packages.

\section{Acknowledgements}

The researcher wishes to thank Mr Theo Botha for his consent and valuable input into this study. I salute his bravery! The researcher is also indebted to Dr Ruth Albertyn, Ms Karlien de Bruin, Ms Anika Berning and Mr Gerrit Marais for their assistance. Lastly, an anonymous reviewer is also thanked for his/her contribution to improve earlier drafts of this article. 
1. The number of companies listed on the JSE decreased from a total of 769 in 1990 to 380 in 2014 (World Federation of Exchanges, 2015). The FTSE/JSE All Share index consists of 160 companies which represent 99 per cent of the total market capitalisation of the exchange (FTSE/JSE Africa index series, 2015).

2. On 31 December 2013, 119 investment managers were registered with the Financial Services Board.

3. As at 31 December 2013, a total of 375 companies were listed on the JSE (World Federation of Exchanges, 2015).

\section{References}

Admati, A.R. \& Pfleiderer, P. 2009. The "Wall Street Walk" and shareholder activism: Exit as a form of voice. The Review of Financial Studies, 22(7): 2645-2685.

Almazan, A., Hartzell, J.C. \& Starks, L. 2005. Active institutional shareholders and the cost of monitoring: evidence from executive compensation. Financial Management, Winter: 5-34.

Anderson, B. 2006. Nampak's governance grilling. Fin24, 8 August. [Online]. Available: http://www.fin24.com/ Companies/Nampaks-governance-grilling-20060208 [Accessed on 7 December 2013].

Apostolides, N. 2007. Directors versus shareholders: evaluating corporate governance in the UK using the AGM scorecard. Corporate Governance: An International Review, 15: 1277-1287.

Armstrong, C.S., Gow, I.D. \& Larcker, D.F. 2013. The efficacy of shareholder voting: evidence from equity compensation plans. Journal of Accounting Research, 51(5): 909-950.

Ashton, M. 2008. Bidvest fields tough questions. Fin24, 17 November. [Online]. Available: http://www.fin24. com/Companies/Bidvest-fields-tough-questions-20081117 [Accessed on 5 June 2014].

Bhagat, S. \& Romano, R. 2009. Reforming executive remuneration and committing to the long-term. Yale Journal on Regulation, 26(2): 359-372.

Barron, C. 2008. Chairmen often can't stand the sight of him. Financial Mail, 20 July. [Online]. Available: http://www.netassets.co.za/article.aspx?id=805975 [Accessed on 5 October 2013].

Barron, C. 2011. Roy McAlpine: A legend is getting off the bus. Times Live, 29 May. [Online]. Available: http://www.timeslive.co.za/business/2011/05/29/newsmaker-roy-mcalpine-a-legend-is-getting-off-thebus [Accessed on 22 January 2014].

Barron, C. 2014a. Something's got to give on CEO pay. Sunday Times Business Times, 18 May. [Online]. Available online: http://www.bdlive.co.za/companies/2014/05/18/something-s-got-to-give-on-ceo-pay [Accessed on 18 May 2014].

Barron, C. 2014b. PIC plays politics with public money. Business Day, 14 July. [Online]. Available: http://www. bdlive.co.za/business/2013/07/14/pic-plays-politics-with-public-money [Accessed on 14 July 2014].

Barry, H. 2014a. Shareholder activist sells views to public. Moneyweb, 1 April. [Online]. Available: http:// www.moneyweb.co.za/moneyweb-corporate-governance/shareholder-activist-sells-views-to-public [Accessed on 1 April 2014].

Barry, H. 2014b. Barclays Africa shareholder cries foul. Moneyweb, 14 April. [Online] Available: http://www. moneyweb.co.za/moneyweb-corporate-governance/absa-shareholder-cries-foul [Accessed on 14 April 2014].

Baue, W. 2002. South African fund applies socially responsible investing principles. Social Funds. [Online]. Available: http://www.socialfunds.com/news/article.cgi/841.html [Accessed on 1 December 2002].

Bauer, R., Moers, F. and Viehs, M. 2012. The determinants of withdrawn shareholder proposals. Social Science Research Network. [Online]. Available: http://ssrn.com/abstract=1885392 [Accessed on 21 January 2015]. 
Becht, M., Franks, J., Mayer, C. and Rossi, S. 2010. Returns to shareholder activism: evidence from a clinical study of the Hermes UK Focus Fund. The Review of Financial Studies, 23(3): 3093-3129.

Benjamin, C. 2009. Avusa shareholder questions bonuses. Business Day, 22 September: 13.

Bhana, N. 2010. The stock market reaction to criticism of corporate governance practices of companies listed on the JSE. Investment Analysts Journal, 72: 1-12.

Boshoff, S. \& Schulshenk, J. 2014. Responsible investment - are South Africa's investors committed? Trialogue. [Online]. Available: http://www.trialogue.co.za/wp-content/uploads/2014/06/FA_Responsibleinvestment_final_Ir.pdf [Accessed on 20 January 2015].

Botha, T. 2014. Be very careful: Two strikes and you're out. Moneyweb, 6 July. [Online]. Available: http:// www.moneyweb.co.za/moneyweb-soapbox/be-very-careful-two-strikes-and-youre-out [Accessed on 6 July 2014].

Bronkhorst, Q. 2014. South Africa's massive wage gap. BusinessTech, 30 May. [Online]. Available: http:// businesstech.co.za/news/general/59173/south-africas-massive-wage-gap/ [Accessed on 30 May 2014].

Burkhardt, P. \& Janse, A, 2014. Everyone in Rustenburg feels pain of mines strike. Business Day, 3 April. [Online]. Available: http://www.bdlive.co.za/national/2014/04/03/everyone-in-rustenburg-feels-pain-ofmines-strike [Accessed on 3 April 2014].

CA Governance. 2014. An introduction. [Online]. Available: http://www.ca-governance.co.za/index.php/ourteam.html [Accessed on 5 June 2014].

Cairns, P. 2014. The future is a risky place. Moneyweb, 21 July. [Online]. Available: http://www.moneyweb. co.za/moneyweb-investment-insights/the-future-is-a-risky-place [Accessed on 21 July 2014].

Carte, D. 2009. M\&F exec pay questioned. Moneyweb, 29 April. [Online] Available: http://www.moneyweb. co.za/moneyweb-financial/mf-exec-pay-questioned?sn=2009+Detail [Accessed on 7 November 2013].

Carte, D. 2010. Standard Bank chairman gets his money. Moneyweb, 27 May. [Online]. Available: http:// www.moneyweb.co.za/moneyweb-financial/standard-bank-chairman-gets-his-money [Accessed on 24 June 2014].

Carte, D. 2011. KWV saga: Theo Botha to Thys du Toit, Jannie Mouton: Resign! Moneyweb, 12 February. [Online]. Available: http://www.moneyweb.co.za/moneyweb-industrials/kwv-saga-theo-botha-to-thysdu-toit-jannie-mouton- [Accessed on 28 November 2013].

Cespa, G. \& Cestone, G. 2007. Corporate social responsibility and managerial entrenchment. Journal of Economics and Management Strategy, 16: 741-761.

Chan, M. 2009. How to rein in executive compensation? The Open Ethics Journal, 3: 81-90.

Cheffins, B.R. \& Thomas, R.S. 2001. Should shareholders have a greater say over executive pay?: Learning from the US Experience. Vanderbilt Law, Joe C. Davis Research Paper No. 01-6. [Online]. Available: http:// ssrn.com/abstract $=268992$ [Accessed on 4 February 2015].

Cobbett, J. 2007. Doubts raised at Dorbyl AGM. Moneyweb, 20 August. [Online]. Available: http://www. moneyweb.co.za/moneyweb-corporate-governance/doubts-raised-at-dorbyl-agm [Accessed on 23 June 2014].

Cohen, T. 2011. The BEE deal that should never have been. Business Day, 28 September: 16.

Cokayne, R. 2009. Activist Botha warns PPC on audit committee chair. Business Report, 27 January 27. [Online]. Available: http://www.highbeam.com/doc/1G1-192635015.html [Accessed on 6 June 2014].

Conyon, M.J. 1997. Corporate governance and executive compensation. International Journal of Industrial Organization, 15: 493-509.

Conyon, M. \& Sadler, G. 2010. Shareholder voting and directors' pay report legislation: say on pay in the UK. Corporate Governance: an International Review, 18(4): 296-312.

Couldridge, D. 2014. Personal communication. Senior Investment Analyst, Element Investment Managers, Cape Town, South Africa. 
Creamer, M. 2009. Sacked Wesizwe CEO scrapes back in pyrrhic victory. Mining Weekly, 17 December. [Online]. Available: http://www.miningweekly.com/article/sacked-wesizwe-ceo-scrapes-back-in-pyhrricvictory-2009-12-17 [Accessed on 1 June 2013].

CRISA (Code for Responsible Investing in South Africa). 2011. Association of Savings and Investments SA, July. [Online]. Available: http://asisa.co.za/asisadocs/CRISA\%20Code\%202011Final.pdf [Accessed on 1 April 2014].

Crotty, A. 2010. Shareholders are missing link in governance codes. Business Day, 25 May. [Online]. Available: http://www.elementim.co.za/element-in-the-news/read/145/ [Accessed on 6 October 2013].

Crotty, A. 2011. Botha grills Nampak for chief's share allocation. Business Report, 14 March. [Online]. Available: http://www.iol.co.za/business/companies/botha-grills-nampak-for-chief-s-share-allocation-1.1041427 [Accessed on 4 May 2014].

Crotty, A. 2012a. Shareholder activist turns up the heat on Barloworld boss's bonus. Business Report, 26 January. [Online]. Available: http://www.iol.co.za/business/business-news/shareholder-activist-turnsup-the-heat-on-barloworld-boss-s-bonus-1.1220474 [Accessed on 20 December 2013].

Crotty, A. 2012b. SA shareholders slow to act on governance. Business Report, 8 May. [Online]. Available: http://www.elementim.co.za/element-in-the-news/read/207/ [Accessed on 6 October 2013].

Crotty, A. 2013a. Anglo’s bonuses called into question. Business Report, 2 August. [Online]. Available: http:// www.iol.co.za/business/news/anglo-s-bonuses-called-into-question-1.1556497 [Accessed on 1 June 2013].

Crotty, A, 2013b. Absa report is better but payouts still unclear. IOL, 3 May. [Online]. Available: http://www. iol.co.za/business/companies/absa-report-is-better-but-payouts-still-unclear-1.1509730 [Accessed on 19 December 2013].

Crotty, A. 2013c. Investor voting disclosure urged. Business Report, 21 January. [Online]. Available: http:// www.elementim.co.za/element-in-the-news/read/265/ [Accessed on 5 June 2013].

Crotty, A. 2014a. SA firms to disclose more. Business Day, 4 May. [Online]. Available: http://www.bdlive.co.za/ businesstimes/2014/05/04/sa-firms-to-disclose-more [Accessed on 4 May 2014].

Crotty, A, 2014b. JSE proposes raft of changes to AGM requirements. Times Live, 13 April. [Online]. Available: http://www.timeslive.co.za/Feeds/2014/04/13/jse-proposes-raft-of-changes-to-agm-requirements [Accessed on 13 April 2014].

Crotty, A. 2014c. Hidden costs of CEO pay bonanzas. Sunday Times Business Times, 10 August: 11.

Davis, S., Lukomnik, J. \& Pitt-Watson, D. 2006. The new capitalists - how citizen investors are reshaping the corporate agenda. Harvard Business School Press: Boston.

Davis, G.F. \& Han Kim, E. 2007. Business ties and proxy voting by mutual funds. Journal of Financial Economics, 85(2): 552-570.

De Bakker, F.G.A. \& Den Hond, F. 2008. Activists' influence tactics and corporate policies. Business and Professional Communication Quarterly, 71(1): 107-111.

Del Guercio, D., Seery, L. \& Woidtke, T. 2008. Do boards pay attention when institutional investor activists "just vote no"? Journal of Financial Economics, 90: 84-103.

Del Guercio, D. \& Tran, H. 2012. Institutional investor activism (pp. 359-380). In: Baker, H.K. \& Nofsinger, J.R. (Eds). Socially responsible finance and investing - financial institutions, corporations, investors and activists. Wiley: Hoboken, NJ.

De Bruin, K. 2014. Personal communication. Senior Investment Analyst, Grayswan Investments, Somerset West, South Africa.

De Waal, M. 2011. High drama at Avusa amid rumours of Prakash Desai's departure. Daily Maverick, 21 September. [Online]. Available: http://www.dailymaverick.co.za/article/2011-09-21-high-drama-atavusa-amid-rumours-of-prakash-desais-departure [Accessed on 21 December 2013].

Delman, J.R. 2010. Structuring say-on-pay: A comparative look at global variations in shareholder voting on 
executive compensation. Columbia Business Law Review, 2: 583-621.

Elo, S. \& Kyngäs, H. 2007. The qualitative content analysis process. Journal of Advanced Nursing, 62(1): $107-115$

Ertimur, Y., Ferri, F. \& Muslu, V. 2010. Shareholder activism and CEO pay. Review of Financial Studies, 24: 535-592.

Faku, D. 2012. Central Rand Gold shareholders rebel. Interactive investors, 26 April. [Online]. Available: http:// www.iii.co.uk/investment/detail?code=cotn:CRND.L\&display=discussion\&id=9594317\&action=detail [Accessed on 2 February 2014].

Faulkender, M., Kadyrzhanova, D., Prabhala, N. \& Senbet, L. 2010. Executive compensation: an overview of research on corporate practices and proposed reforms. Journal of Applied Corporate Finance, Winter: $107-118$.

Ferri, F. \& Maber, D.A. 2013. Say on pay votes and CEO compensation: Evidence from the UK. Review of Financial Studies, 17(2): 527-563.

Filen, C. 2012. Shareholders ask questions of AMSA CEO's pay hike. Mineweb, 16 May. [Online]. Available: http://www.mineweb.com/mineweb/content/en/mineweb-finance-politics?oid=151556\&sn=Detail\&p $\mathrm{id}=103364$ [Accessed on 2 February 2014].

FTSE/JSE Africa index series. 2015. JSE. [Online]. Available: https://www.jse.co.za/services/market-data/ indices/ftse-jse-africa-index-series/headline [Accessed on 5 February 2015].

FTSE/JSE Africa Index Series. 2014. JSE. [Online]. Available: https://www.jse.co.za/services/market-data/ indices/ftse-jse-africa-index-series [Accessed on 1 June 2014].

Fumpa, H. 2011. Investigating the role of trade unions in pension fund investment: A case of trade unions in South Africa. Unpublished MA research report, University of the Witwatersrand: Johannesburg, South Africa.

Gardee, R. 2014. BEE shareholder activism set to rise. Moneyweb, 5 March. [Online]. Available: http://www. moneyweb.co.za/moneyweb-soapbox/bee-shareholder-activism-set-to-rise [Accessed on 5 March 2014].

GEPF (Government Employees Pension Fund). 2015a. About us. [Online]. Available: http://www.gepf.gov.za/ index.php/about_us/article/who-is-gepf [Accessed on 30 January 2015].

GEPF (Government Employees Pension Fund). 2015b. Responsible investing. [Online]. Available: http://www. gepf.gov.za/index.php/investments/socially-responsible-investment [Accessed on 30 January 2015].

Gifford, J.E. 2010. Effective shareholder engagement: The factors that contribute to shareholder salience. Journal of Business Ethics, 92(1): 79-97.

Gillan, S.L. \& Starks, L.T. 2000. Corporate governance proposals and shareholder activism: the role of institutional investors. Journal of Financial Economics, 57: 275-305.

Gillan, S.L. \& Starks, L.T. 2007. The evolution of shareholder activism in the United States. Journal of Applied Corporate Finance, 19(1): 55-73.

Gilmour, J. 2013. JD shareholders want answers. Moneyweb, 21 November. [Online]. Available: http:// www.moneyweb.co.za/moneyweb-corporate-governance/jd-shareholders-want-answers [Accessed on 21 November 2013].

Gilmour, J. 2014. No-show Peter Matlare gets reappointed to Barclays Africa. Moneyweb, 6 May. [Online]. Available: http://www.moneyweb.co.za/moneyweb-financial/noshow-peter-matlare-gets-reappointedto-barclays- [Accessed on 6 May 2014].

Goodstein, J.D. \& Wicks, A.C. 2007. Corporate and stakeholder responsibility: making business ethics a twoway conversation. Business Ethics Quarterly, 17(3): 375-398.

Guay, T., Doh, J.P. and Sinclair, G. 2004. Non-governmental organizations, shareholder activism and socially responsible investments: ethical, strategic and governance implications. Journal of Business Ethics, 52(1): 125-139. 
Hadani, M., Goranova, M. \& Khan, R. 2011. Institutional investors, shareholder activism and earnings management. Journal of Business Research, 64(12): 1352-1360.

Harraway, R., Moopanar, M., McCabe, R. \& Sika, A. 2012. Remuneration governance - 2012 survey results. Ernest \& Young, April. [Online]. Available: http:/c.ymcdn.com/sites/www.iodsa.co.za/resource/collection/ DD8B591E-3D00-48D5-B2E9-663FEDCFF131/EY_2012_Remuneration_Governance_Survey_Results.pdf [Accessed on 7 November 2013].

Harris, S. 2013. Sappi is a serial underperformer. Financial Mail, 15 August. [Online]. Available: http:// www.financialmail.co.za/business/money/2013/08/15/sappi-is-a-serial-underperformer [Accessed on 15 August 2013].

Hasenfuss, M. 2006. Who is Theo Botha? Finweek, 13 July: 12.

Hasenfuss, M. 2009a. Super Group: losing Larry's legacy. Fin24, 17 April. [Online]. Available: http://www. fin24.com/Companies/Super-Group-losing-Larrys-legacy-20090417 [Accessed on 25 June 2014].

Hasenfuss, M. 2009b. Brand damage. Fin24, 27 November. [Online]. Available: http://www.fin24.com/Opinion/ Columnists/Marc-Hasenfuss/Brand-damage-20091127 [Accessed on 23 June 2014].

Heese, K. 2005. The development of socially responsible investment in South Africa: experience and evolution of SRI in global markets. Development Southern Africa, 22(5): 729-739.

Hedley, N. 2013. Call for improved disclosure of executive bonuses. Business News, 21 November. [Online]. Available: http://bu sinessnews.howzit.msn.com/call-for-improved-disclosure-of-executive-bonuses [Accessed on 4 May 2014].

Hendry, J., Sanderson, P., Barker, R. \& Roberts, J. 2007. Responsible ownership, shareholder value and the new shareholder activism. Competition \& Change, 11(3): 223-240.

Herringer, A., Firer, C. \& Viviers, S. 2009. Key challenges facing the socially responsible investment (SRI) sector in South Africa. Investment Analysts Journal, 70(Nov): 11-26.

Hogg, A. 2008. Gold Reef's proposed share incentive scheme amended. Theo Botha - shareholder activist. Moneyweb, 19 August. [Online]. Available: http://www.moneyweb.co.za/moneyweb-safm-marketupdate/gold-reefs-proposed-share-incentive-scheme-amended?sn=2009+Detail [Accessed on 5 October 2013].

Hogg, A. 2009. AGMs, shareholder activism, remuneration committees, directors: Theo Botha - shareholder activist. Moneyweb, 2 October. [Online]. Available: http://www.moneyweb.co.za/moneyweb-safmmarket-update/agms-shareholder-activism-remuneration-committees- [Accessed 4 April 2013].

Hogg, A. 2010. Sasol executive remuneration: Theo Botha - shareholder activist. Moneyweb, 30 November. [Online]. Available: http://www.moneyweb.co.za/moneyweb-safm-market-update/sasol-executiveremuneration-theo-botha--shareholdhttp://www.moneyweb.co.za/moneyweb-safm-market-update/ sasol-executive-remuneration-theo-botha--sharehold [Accessed on 4 April 2013].

Huppé, G.A. \& Bala-Miller, P. 2011. Shareholder passivity: a viable explanation for corporate governance failures at NewsCorp? Journal of Sustainable Finance and Investment, 1: 180-194.

Irvine, W.B. 1987. The ethics of investing. Journal of Business Ethics, 6: 233-242.

Jensen, M.C. \& Murphy, K.J. 1990. CEO incentives - it's not how much you pay, but how you pay. Harvard Business Review, 3: 138-153.

Jolly, P. \& Bozinovski, G. 2013. Two strikes rule - playing by the rules. Keeping Good Companies, 65(1): 5-7.

Judge, W.Q., Guar, A. \& Muller-Kahle, M.I. 2010. Antecedents of shareholder activism in target firms: evidence from a multi-country study. Corporate Governance: An International Review, 18(4): 258-273.

Karpoff, J.M., Malatesta, P.H. \& Walkling, R.A. 1996. Corporate governance and shareholder initiatives: empirical evidence. Journal of Financial Economics, 42: 365-395.

Keeping tycoons on their toes. 2007. Mail \& Guardian, 10 May. [Online]. Available: http://www.mg.co.za/ article/2007-05-10-keeping-tycoons-on-their-toes [Accessed on 2 April 2013] 
Lekhesa, M.W. 2009. Shareholder activism: The birth of a new phenomenon in South African corporate law. The Department of Mercantile Law, University of the Free State: Bloemfontein, South Africa.

Levitt, A. 2004. Money, Money, Money. The Wall Street Journal, 22 November. [Online]. Available: http://www. wsj.com/articles/SB110108304413780419 [Accessed on 2 January 2015].

Mamtse, D. 2007. Theo Botha - shareholder activist, troublemaker. Moneyweb, 5 February. [Online]. Available: http://www.moneyweb.co.za/moneyweb-ict/theo-botha--shareholder-activist-troublemaker [Accessed on 6 February 2013].

Mantshantsha, S. 2007. Astral found wanting on BEE. Fin24, 15 February. [Online]. Available: http://www. fin24.com/Companies/Astral-found-wanting-on-BEE-20070215 [Accessed on 13 December 2013].

Mantshantsha, S. 2010. Keeping reasons under wraps. Finweek, 25 February: 29.

Mantshantsha, S. 2013. Is the PIC too tame? Financial Mail, 13 December. [Online]. Available: http://www. financialmail.co.za/markets/2012/12/13/is-the-pic-too-tame [Accessed on 13 December 2013].

Mathews, C. 2014. Anglo confident cutbacks will deliver. Business Day, 25 April. [Online]. Available: http:// www.bdlive.co.za/business/mining/2014/04/25/anglo-confident-cutbacks-will-deliver [Accessed on 25 April 2014].

Mathews, C. \& Hasenfuss, M. 2013. Money talks. Financial Mail, 23 May. [Online] Available: http://www. fm.co.za/business/money/2013/05/23/money-talks [Accessed on 23 May 2013].

McLaren, D. 2004. Global stakeholders: corporate accountability and investor engagement. Corporate Governance, 12(2): 191-201.

Meznar, M.B., Nigh, D. \& Kwok, C.C.Y. 1998. Announcements of withdrawal from South Africa revisited: making sense of contradictory event study findings. Academy of Management Journal, 41(6): 715-730.

Mokopanele, T. 2008. PPC chairman grilled over multiple posts. Business Day, 29 January. [Online]. Available: http://business.highbeam.com/3548/article-1G1-173962872/ppc-chairman-grilled-over-multiple-posts [Accessed on 4 June 2014].

Monteiro, J. 2009. Outcry over Sappi CEO’s bonus. Fin24, 2 March. [Online]. Available: http://www.fin24.com/ Companies/Outcry-over-Sappi-CEOs-bonus-20090302 [Accessed on 17 March 2013].

Morgan, A., Poulsen, A., Wolf, J. \& Yang, T. 2011. Mutual funds as monitors: evidence from mutual fund voting. Journal of Corporate Finance, 17(4): 914-928.

Mpofu, B. 2013. Minority shareholders bear burden of corporate politics: Part 1. Newsday, 28 March. [Online]. Available: http://www.newsday.co.zw/2013/03/28/minority-shareholders-bear/ [Accessed on 28 March 2013].

Naidoo, R. 2002. Corporate governance: An essential guide for South African companies. Cape Town: Juta.

Ndzamela, P. 2014. Standard Bank defends the amount paid to its CEOs. Business Day, 30 May. [Online]. Available: http://www.bdlive.co.za/business/financial/2014/05/30/standard-bank-defends-the-amountpaid-to-its-ceos [Accessed on 30 May 2014].

Nordén, L. \& Strand, T. 2011. Shareholder activism among portfolio managers: rational decision or 15 minutes of fame? Journal of Management Governance, 15: 375-391.

Ng, L., Wang, Q. \& Zaiats, N. 2009. Firm performance and mutual fund voting. Journal of Banking and Finance, 33(12): 2270-2217.

Ntim, C.G., Opong, K.K. \& Danbolt, J. 2012. The relative value relevance of shareholder versus stakeholder corporate governance disclosure policy reforms in South Africa. Corporate Governance: An International Review, 20(1): 84-105.

Paine, L.S. 1994. Managing for organisational integrity. Harvard Business Review, 72(2): 106-117.

Palmon, D., Santoro, M.A. \& Strauss, R. 2009. Pay now, lose later: the role of bonuses and non-equity incentives in the financial meltdown of 2007-2009. The Open Ethics Journal, 3: 76-80. 
Patton, C. 2014. Amplats chair 'not deaf' to executive pay furore. Business Day, 19 May. [Online]. Available: http://www.bdlive.co.za/business/mining/2014/05/19/amplats-chair-not-deaf-to-executive-pay-furore [Accessed on 19 May 2014].

Petros, N. 2009. Botha has his say, but Remgro gets to unwrite story. The Star, 18 August: 2.

Phillips, R.A. 1997. Stakeholder theory and a principle of fairness. Business Ethics Quarterly, 7(1): 51-66.

PIC (Public Investment Corporation). 2015. Welcome to the Public Investment Corporation. [Online]. Available: http://www.pic.gov.za/ [Accessed on 1 March 2015].

Picketty, T. 2014. Capital in the twenty-first century. Harvard University Press: Boston.

Pickworth, E. 2014. SA has among widest pay gaps, report shows. Business Day, 29 May. [Online]. Available: http://www.bdlive.co.za/business/2014/05/29/sa-has-among-widest-pay-gaps-report-shows [Accessed on 4 August 2014].

Planting, S. 2012. We need more capitalist activists - Theo Botha. Moneyweb, 29 February. [Online]. Available: http://www.moneyweb.co.za/moneyweb-corporate-governance/we-need-more-capitalist-activists-theo-botha [Accessed on 21 May 2013].

Proffitt, W.T. (Jr) \& Spicer, A. 2006. Shaping the shareholder activism agenda: institutional investors and global social issues. Strategic Organisation, 4(2): 165-190.

Poulsen, T., Strand, T. \& Thomsen, S. 2010. Voting power and shareholder activism: as study of Swedish shareholder meetings. Corporate Governance: An International Review, 18(4): 329-343.

Purcell, N. 2011. Heads I win, tails you lose - the need to reform executive compensation. Journal of International Business Ethics, 4(1): 3-9.

Rademeyer, C. \& Holtzhausen, J. 2004. King II, corporate governance and shareholder activism. South African Law Journal, 120(4): 767-775.

Remuneration Governance in South Africa - 2013 Survey results. 2013. Ernest \& Young. [Online]. Available: http://www.ey.com/Publication/vwLUAssets/Remuneration_Governance_in_South_Africa/\$FILE/EY\%20 2103\%20Survey\%20Remuneration\%20Governance.pdf [Accessed on 1 April 2014].

Renneboog, L., Ter Horst, J. \& Zhang, C. 2008. Socially responsible investments: Institutional aspects, performance and investor behaviour. Journal of Banking and Finance, 32: 1723-1742.

Reddy, R. \& Giamporcaro, S. 2011. Trade Unions and Sustainable and Responsible Investing: trustees, shop stewards, members: Who should be trusted with getting forward with SRI in South Africa? Unpublished MBA research paper, University of Cape Town Graduate School of Business: Cape Town, South Africa.

Robbins, T. 2008. PIC hails promotion of women at New Clicks. E-spaces, 6 February. [Online]. Available: http://espaces.wordpress.com/2008/02/07/pic-hails-promotion-of-women-at-new-clicks/ [Accessed on 4 May 2014].

Rose, R. 2007. Bashful activist raises hackles of corporate SA. Business Day, 9 February. [Online]. Available: http://allafrica.com/stories/200702090818.html [Accessed on 4 June 2014].

Rose, R. 2014. Facile justification for odious pay hikes. Sunday Times Business Times, 18 May. [Online]. Available: http://www.bdlive.co.za/businesstimes/2014/05/18/facile-justification-for-odious-pay-hikes [Accessed on 18 May 2014].

Rose, R. \& Shevel, A. 2009. SABMiller loses its cheer for PIC's Molefe. Sunday Times Business Times: 2 August: 1.

Schumacher, I. \& Monteiro, J. 2009. Desai grilled at Avusa AGM. Fin24, 21 September. [Online]. Available: http://www.fin24.com/Companies/Desai-grilled-at-Avusa-AGM-20090921 [Accessed on 22 December 2014].

Shleifer, A. \& Vishny, R. 1986. Large shareholders and corporate control. Journal of Political Economy, 94: 461-448.

Shevel, A. 2014. Terrier-like Botha keeps companies on a leash. Sunday Times Business Times, 2 February. [Online]. Available: http://www.bdlive.co.za/business/2014/02/02/terrier-like-botha-keeps-companieson-a-leash [Accessed on 2 February 2014]. 
Short, H. \& Keasey, K. 1999. Managerial ownership and performance of firms: Evidence from the UK. Journal of Corporate Finance, 5: 79-101.

Silverman, G. \& Duncan, J. 2014. Responsible investment - are South Africa's investors committed? EY Trialogue Sustainability Forum, 28 August, Available from author.

Sjöstrom, E. 2008. Shareholder activism for corporate social responsibility. Sustainable Development, 16(3): $141-154$.

Steyn, L. 2011. Theo Botha - the shareholder activist. Mail \& Guardian, 13 May. [Online]. Available: http:// mg.co.za/article/2011-05-13-theo-botha-the-shareholder-activist [Accessed on 18 February 2013].

Tau, S. 2014. Amcu strike hitting Rustenburg hard. The Citizen, 25 March. [Online]. Available: http://citizen. co.za/149107/amcu-strike-hitting-rustenburg-hard/ [Accessed 25 July 2014].

Tredway, G. 2004. Aflease activist attacked. Mineweb, 23 September. [Online]. Available: http://www. mineweb.com $/$ mineweb/content/en/mineweb-historical-daily-news?oid=13495\&sn=Daily+news+Detail [Accessed on 4 May 2014].

Thomas, R.S. \& Martin, K.J. 1999. The effect of shareholder proposals on executive compensation. University of Cincinnati Law Review, 67: 1021-1081.

UNPRI (United Nations Principles for Responsible Investment). 2015. The Six Principles. [Online] Available: http://www.unpri.org/about-pri/the-six-principles/ [Accessed on 21 January 2015].

Vallie, A. 2011. Spur meets resistance on directors' pay. Business Day, 12 August. [Online] Available: http:// www.sanlam.co.za/wps/wcm/connect/1e81c2004da06698aef6aeb6a2a1e1a5/Spur+meets+resistance+on+ directors.pdf?MOD=AJPERES [Accessed on 4 April 2014].

Vanek, M. 2012a. Absa's murky pay structure. Moneyweb, 3 May. [Online]. Available: http://www.moneyweb. co.za/moneyweb-financial/absas-murky-pay-structure [Accessed on 4 June 2014].

Vanek. M. 2012b. JD Group AGM gets personal. Moneyweb, 16 February. [Online]. Available: http://www. moneyweb.co.za/moneyweb-industrials/jd-group-agm-gets-personal [Accessed on 4 June 2014].

Vanek, M. 2012c. Investec's CEO strikes back at AGM critics. Moneyweb, 6 August. [Online]. Available: http:// www.moneyweb.co.za/moneyweb-financial/investecs-ceo-strikes-back-at-agm-critics?sn $=2009 \% 20$ Detail [Accessed on 13 October 2012].

Van Niekerk, R. 2014. Mind the (wage) gap. Moneyweb, 21 May. [Online]. Available: http://www.moneyweb. co.za/moneyweb-south-africa/mind-the-wage-gap [Accessed on 21 May 2014].

Veitch, M.C. 1995. The role of institutional investors towards critical issues of corporate governance in South Africa. Unpublished MBA thesis. University of Stellenbosch Business School: Stellenbosch, South Africa.

Vitulano, L.A. \& Hannafey, F.J. 2009. Economic, moral, and motivational criteria of executive compensation: recent developments. The Open Ethics Journal, 3:67-70.

Viviers, S., Bosch, J.K., Smit, E.vd M. \& Buijs, A. 2009. Responsible investing in South Africa. Investment Analysts Journal, 69(May): 1-14.

Waddock, S. \& Graves, S.B. 2004. Understanding shareholder activism: which corporations are targeted? Business and Society, 43(3): 239-267.

Wen, S. 2009. Institutional investor activism on socially responsible investment: effect and expectations. Business Ethics: A European Review, 18(3): 308-333.

Winfield, J. 2011. The landscape of proxy voting at South African asset managers. July. [Online]. Available: http://www.riscura.com/docs/research/SpoiltVotesHigh_Aug2011.pdf [Accessed on 20 December 2013].

Whitfield, B. 2011. Storm in a B-Cup. Finweek, 6 September: 7.

World Federation of Exchanges. 2015. Annual Query Tool - Listed Companies. [Online]. Available: http:// www.world-exchanges.org/statistics/annual-query-tool [Accessed on 4 February 2015]. 


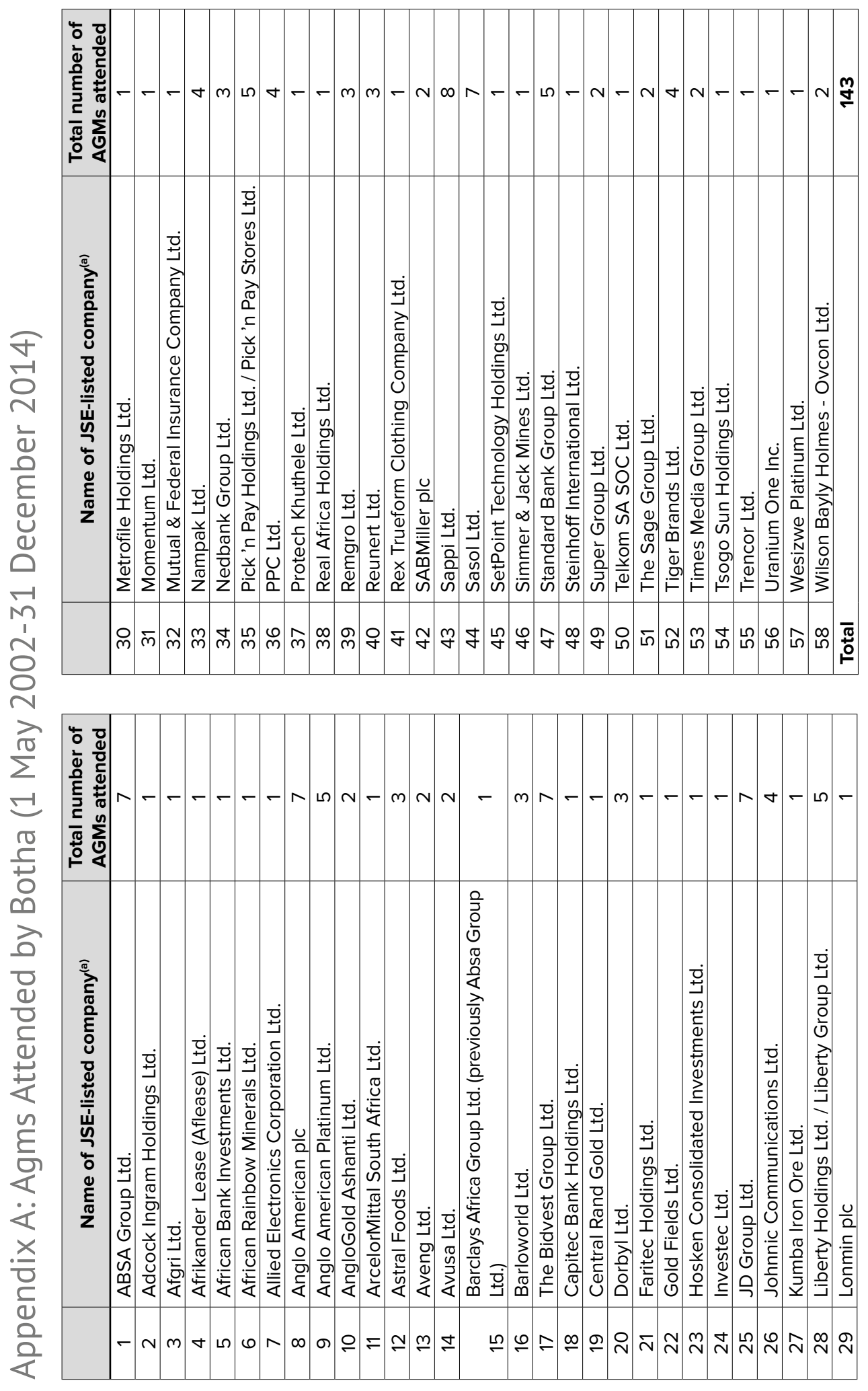

